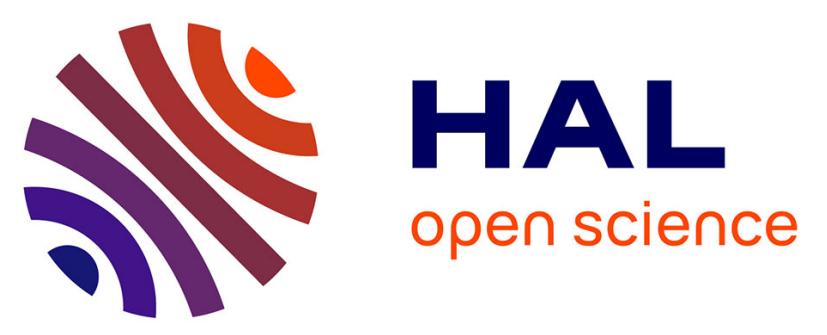

\title{
MÖSSBAUER SPECTROSCOPIC STUDY OF 19 ELECTRON ORGANOMETALLIC PARAMAGNETIC SANDWICHES n5-C5R5Fe(I)n6-C6R'6.
}

J. Mariot, F. Varret, P. Michaud, Dominique Astruc, J.-R. Hamon, G. Althoff, P. Batail

\section{To cite this version:}

J. Mariot, F. Varret, P. Michaud, Dominique Astruc, J.-R. Hamon, et al.. MÖSSBAUER SPECTROSCOPIC STUDY OF 19 ELECTRON ORGANOMETALLIC PARAMAGNETIC SANDWICHES n5-C5R5Fe(I)n6-C6R'6.. Journal de Physique Colloques, 1980, 41 (C1), pp.C1-319-C1-320. 10.1051/jphyscol:19801117 . jpa-00219599

\section{HAL Id: jpa-00219599 https://hal.science/jpa-00219599}

Submitted on 1 Jan 1980

HAL is a multi-disciplinary open access archive for the deposit and dissemination of scientific research documents, whether they are published or not. The documents may come from teaching and research institutions in France or abroad, or from public or private research centers.
L'archive ouverte pluridisciplinaire HAL, est destinée au dépôt et à la diffusion de documents scientifiques de niveau recherche, publiés ou non, émanant des établissements d'enseignement et de recherche français ou étrangers, des laboratoires publics ou privés. 
MÖSSBAUER SPECTROSCOPIC STUDY OF 19 ELECTRON ORGANOMETALLIC PARAMAGNETIC SANDWICHES $\eta^{5}-C_{5} R_{5} F_{e}(I) \eta_{n}{ }^{6} C_{6} R^{\prime}{ }_{6}$

J.P. Mariot, F. Varret, P. Michaud, D. Astruc ${ }^{+a}$, Jn.R. Hamon ${ }^{+a}$, G. Althoff ${ }^{+a}$ and P. Batail ${ }^{+b}$

Laboratoire de Spectrométrie Mössbauer, Université du Maine, 72017 LE MANS CEDEX.

+ Laboratoire a) de Chimie des Organométalliques b) de Cristallochimie, Université de Rennes, Campus de Becallieu, 35042 RENNES CEDEX.

1. Introduction. -

The most known organometallic sandwich is ferrocene which is a $\mathrm{Fe}(\mathrm{II})$ sandwich fullfilling the 18 electrons rule, i.e they are 18 electrons in the iron valence shell. This compound is diamagnetic and its electronic properties have already been calculated with an MO model $/ 1 /$. $\mathrm{Fe}$ (II) $d^{6}$ cations have been synthesized through exchange ligand experiments $/ 2 /$. Mossbauer hyperfine parameters (fig.1) are found to be similar to that of ferrocene (for ferrocene IS $=0.43 \mathrm{~mm} / \mathrm{s}$ and $Q S=2,38 \mathrm{~mm} / \mathrm{s}$ at room temperature). By reducing the cations /2/ we obtain 19 electron $\mathrm{Fe}$ (I) paramagnetic $\left(\mu=1,8 \mu_{B}\right)$ sandwiches which are very sensitive to air action. Thus the Mossbauer samples were very carefuliy prepared and conditionned under nitrogen inert atmosphere. As a striking example it is worth noting oxygen action on $\mathrm{C}_{5} \mathrm{H}_{5} \mathrm{FeC}_{6}\left(\mathrm{CH}_{3}\right)_{6}$ (I) leading to $0_{2}^{-}$, a mode active in aging of living cells $/ 3 /$. We grew crystals for $\underline{1}$ (fig. 6) on $1 y$.

\section{Results and discussion. -}

From $4.2 \mathrm{~K}$ to room temperature powder quadrupolar spectra are observed. (fig.3). We must notice the IS of $\mathrm{Fe}$ (I) compounds higher than that of $\mathrm{Fe}$ (II) ones as expected because of their lower oxydation state. The 19th delectron is in an $\mathrm{e}_{1 \mathrm{~g}} \mathrm{~g}^{*} / 4 /$ degenerate orbital. The contribution of a $\mathrm{e}_{1 \mathrm{~g}}$ electron to the EFG being around $2 \mathrm{~mm} / \mathrm{s} / 5 /$, we can roughly estimate the 19 th electron iron character by comparing the QS of the cation and the radical. For most of the compounds the difference in $Q S$ is around $1.5 \mathrm{~mm} / \mathrm{s}$ (fig.2) Teading to $\frac{1.5}{2}=75 \%$ iron character.

To 71 ustrate the different oxydation states succesiveny observed during the full study of one particular sandwich we show on fig. 3 the spectra of a) the former cation (18 $e^{-} d^{6}$ yellow)

b) the radical (19 $\mathrm{e}^{-} \mathrm{d}^{7}$ green)

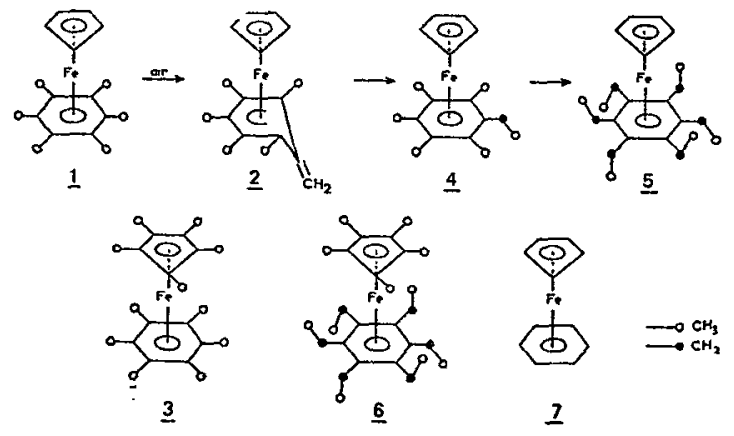

Fig. 1 : The studied series of $\mathrm{Fe}$ (I) radicals |except $\underline{2}$ which is a Fe(II) complex|

\begin{tabular}{|c|c|c|c|c|c|}
\hline Fe(l) sandwiches & $\mathrm{O} / \mathrm{Fe}$ & $\mathrm{SQ}_{\mathrm{m} / \mathrm{s}}$ & Cations $\mathrm{PF}_{6}^{-}$ & $\underset{N \rightarrow 15}{D} \mid / F e$ & $\underset{1}{S Q m e s}$ \\
\hline $\mathrm{C}_{5} \mathrm{H}_{5} \mathrm{FeC} 6_{6} \mathrm{CH}_{36}$ & $\begin{array}{l}085 \\
074 \\
074\end{array}$ & $\begin{array}{l}055118 \\
0.50 \\
0.50\end{array}$ & $\begin{array}{l}-77 \mathrm{~K} \\
=\mathrm{RT} \\
\end{array}$ & $\begin{array}{l}0.56 \\
045 \\
\end{array}$ & $\begin{array}{r}200 \\
200 \\
200 \\
\end{array}$ \\
\hline $\left.\mathrm{C}_{5} \mathrm{H}_{5} \mathrm{FeC} 8 \mathrm{ICH}_{3}\right)_{2} \mathrm{C}_{2} \mathrm{H}_{5}^{\circ}$ & $\begin{array}{r}083 \\
073 \\
\end{array}$ & $\begin{array}{r}0.2116 \\
050 \\
\end{array}$ & & & \\
\hline $\mathrm{C}_{5} \mathrm{H}_{5} \mathrm{FeC} \mathrm{C}_{6}^{\circ}$ & 087 & $\begin{array}{r}095 \\
0.938 \\
\end{array}$ & & $\begin{array}{r}052 \\
041\end{array}$ & $\begin{array}{r}164 \\
164 \\
\end{array}$ \\
\hline $\mathrm{C}_{5}\left(\mathrm{CH}_{3}\right)_{5} \mathrm{FeC} \mathrm{CO}_{3}\left(\mathrm{CH}_{3}\right.$ & $\begin{array}{l}081 \\
074 \\
\end{array}$ & $\begin{array}{r}129 \\
054 \\
\end{array}$ & & $\begin{array}{r}052 \\
049 \\
\end{array}$ & $\begin{array}{r}172 \\
172 \\
\end{array}$ \\
\hline $\mathrm{C}_{5} \mathrm{H}_{5} \mathrm{FeC}\left(\mathrm{C}_{2} \mathrm{H}_{5}\right)_{6}^{\circ}$ & $\begin{array}{l}084 \\
0873 \\
073\end{array}$ & $\begin{array}{l}140 \\
07 \\
07\end{array}$ & & $\begin{array}{l}032 \\
0.41 \\
0.49\end{array}$ & $\begin{aligned} 1966 \\
196 \\
\end{aligned}$ \\
\hline
\end{tabular}

Precision $: 0.01 \mathrm{~mm} / \mathrm{s}$.

Fig. 2 : Mossbauer hyperfine data for $d^{6}$ cations and $d^{\top}$ radicals.

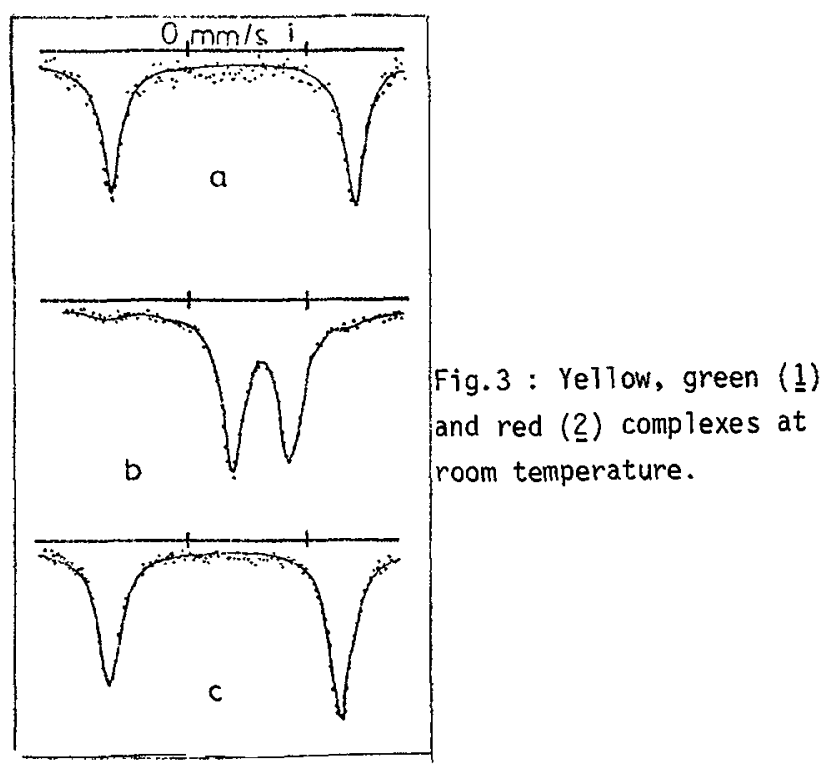




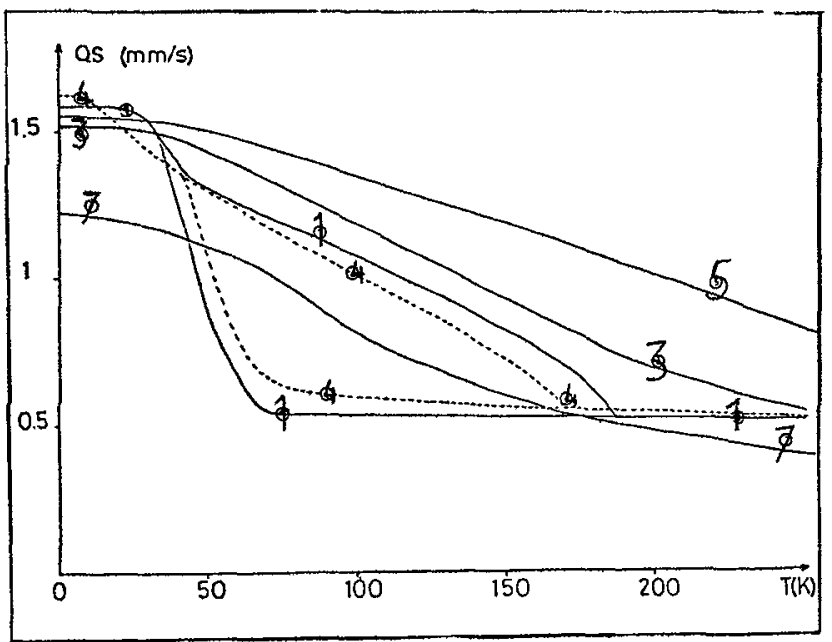

Fig. 4: Temperature dependence of the quadrupole splitting QS.

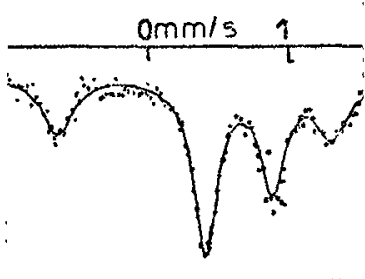

Fig. 6 : Aligned crystals of $\mathrm{C}_{5} \mathrm{H}_{5} \mathrm{Fe}\left(\mathrm{CH}_{3}\right)_{6}$ at room temperature for the following two configurations : Upper spectrum : EFG axe is perpendicular to rray. The outer peaks are those

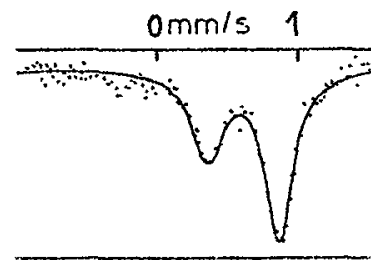
of the axydized (2) form. Lower spectrum : EFG axe is parallel to rray. The crystals were positionned with $R X$ results.

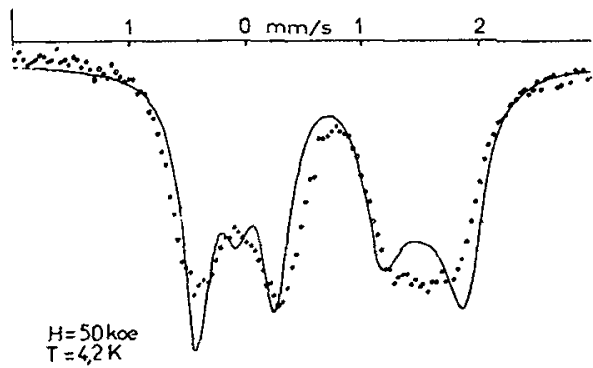

Fig.5 : Green complex (1) under a 5 T magnetic field.

The fit was done with a positive and axial EFG. c) the oxydized form ( $18 e^{-} d^{6}$ red).

The $d^{7}$ complexes having a single electron on the $\mathrm{e}_{1 \mathrm{~g}}{ }^{*}$ level are Jahn-Teller systems $/ 4 /$. The low temperature Jahn-Teller distorsion is orthorhombic /4/ and is responsible for the thermal variation of QS (Fig. 4). Assuming a Boltzmann law for thermal population of the electronic levels, the energy splitting of the $e_{1 g}$ levels was determined in the range $100 \mathrm{~cm}^{-1}, 140 \mathrm{~cm}^{-1}$ for $\underline{3}, \underline{6}, \underline{7}$.

A particalar behaviour is exhibited by $\mathrm{C}_{5} \mathrm{H}_{5} \mathrm{Fe}\left(\mathrm{CH}_{3}\right)_{6}$. This compound keeps a symmetrical potential above $185 \mathrm{~K}$ (constant quadrupole splitting). Below $185 \mathrm{~K}$ the spectrum splits into two quadrupole doublets (fig. 4) indicating a phase transition (probably due to a cooperative JahnTeller effect). This phase transition has been confirmed by $\mathrm{RX}$ resuits at $100 \mathrm{~K}$ and $300 \mathrm{~K}$. The spectrum under magnetic field /6/ at $4.2 \mathrm{~K}$ (fig. 5) shows that the EFG sign is positive. $A-2,3 \mathrm{~T}$ hyperfine field for a $5 \mathrm{~T}$ applied field is observed in agreement with the paramagnetic character previously found. From a ligned single crystal experiments (fig. 6) the EFG sign at room temperature was found to be positive as well.

Our aim is now to investigate this interestirig electronic system :

- determination of ligand field parameters and hyperfine field anisotropy

- characterization of high symmetry matrices in order to observe vibronic effects at low temperature.

\section{References}

/1/ NAGY, G., DESZI, I., HILLMAN, M. J. Physique Colloq, 37 (1976) C6-471.

12/ Laboratoire de Chimie des Organométalliques 35042 Rennes.

/3/ ASTRUC D., ROMAN E., HAMON J.R., BATAIL P., J. Amer. Chem. Soc 101(1979) 2240.

14/ AMMETER J.H., and SWALEN J.D. J. Chem. Phys. 5A (1972) 678/

15/ VARRET F. J. Phys. C6 (1976) 437.

16/ Experiment realised in collaboration with P. IMBERT CEA SACLAY. 